\title{
A METHODOLOGICAL BASIS FOR LANDSCAPE INTERPRETATION: THE CASE OF THE LJUBLJANA MARSH
}

Aleš Smrekar, Mateja Šmid Hribar, Jernej Tiran, Bojan Erhartič $\dagger$

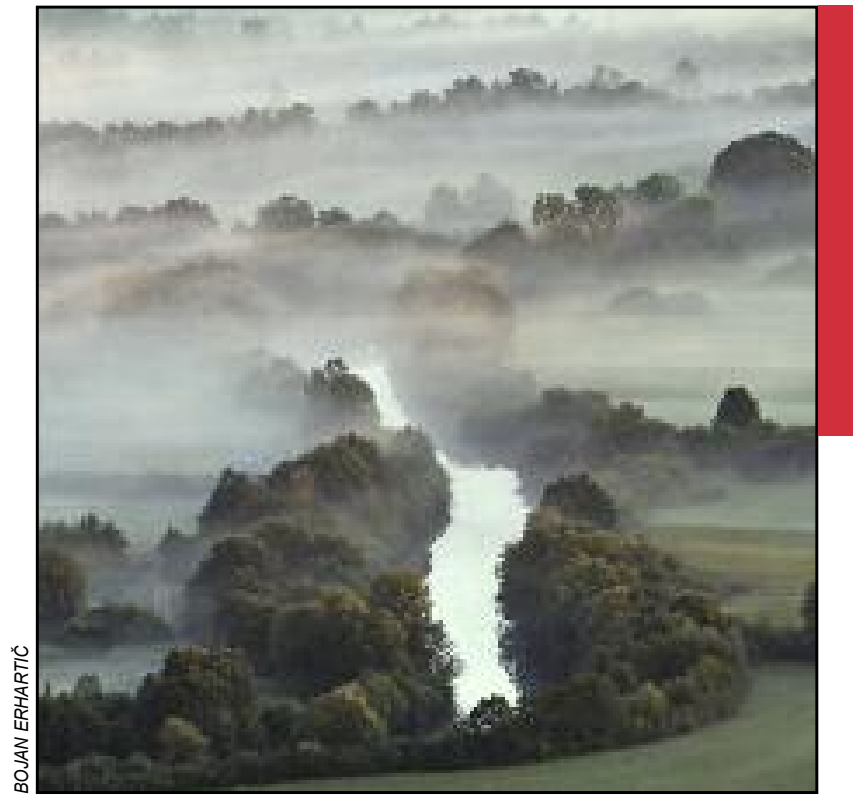

The Ljubljana Marsh is a valuable protected area for Slovenia. 


\section{A methodological basis for landscape interpretation: the case of the Ljubljana Marsh}

DOI: http://dx.doi.org/10.3986/AGS.875

UDC: $911.53: 502.1$ (497.4Lj.barje)

COBISS: 1.01

ABSTRACT: Landscape interpretation is one of the best-suited and established forms of informing and raising the awareness of visitors and local residents. The literature contains only rare examples of useful methodology that could help managers with the initial steps of interpretation. A methodological basis for landscape interpretation is presented, using the case of the Ljubljana Marsh. The form consisting of eight thematic categories is a useful tool for identifying suitable topics and selecting the right interpretation tools. Using this form, managers will reach their final interpretation goal more easily: to make people recognize the landscape and protect it against inappropriate changes.

KEY WORDS: geography, interpretation, protected area, heritage, cultural landscape, management, Ljubljana Marsh, Slovenia

The article was submitted for publication on July $24^{\text {th }}, 2014$.

ADDRESSES:

Aleš Smrekar, Ph.D.

Anton Melik Geographical Institute

Research Center of the Slovenian Academy of Sciences and Arts

Novi trg 2, SI - 1000 Ljubljana, Slovenia

E-mail: ales.smrekar@zrc-sazu.si

Mateja Šmid Hribar, Ph.D.

Anton Melik Geographical Institute

Research Center of the Slovenian Academy of Sciences and Arts

Novi trg 2, SI - 1000 Ljubljana, Slovenia

E-mail:mateja.smid@zrc-sazu.si

Jernej Tiran, Ph.D.

Anton Melik Geographical Institute

Research Center of the Slovenian Academy of Sciences and Arts

Novi trg 2, SI - 1000 Ljubljana, Slovenia

E-mail: jernej.tiran@zrc-sazu.si

Bojan Erhartič $\nmid$ Ph.D.

Anton Melik Geographical Institute

Research Center of the Slovenian Academy of Sciences and Arts

Novi trg 2, SI - 1000 Ljubljana, Slovenia 


\section{Introduction}

People have always wanted to understand and explain the world around them. Various cultures have explained and admired their local landscapes, their products, and their people's stories (Colquhoun 2005). Interpreting nature, heritage, the environment, or landscape is a more recent phenomenon and is one of the best-suited and established forms of informing and raising the awareness of visitors and local residents.

Within this context, the term »interpretation « was first used by John Muir in 1871. He wrote the following in his notebook: »'ll interpret the rocks ..., «in which he was referring more to understanding than communicating (Mackintosh 2013). The American naturalist Enos Mills held professional discussions on the natural surroundings and led excursions into the wilderness as early as the beginning of the twentieth century (Internet 1). Later on, his methods became the basis for modern interpretation in the National Park Service (Internet 2). A few decades later, the term interpretation was defined by Freeman Tilden (1957), who laid the foundations for the profession of heritage interpretation as it is understood today (Kye 2005). Tilden (1957) defined interpretation as an educational activity that aims to reveal meanings and relationships using original objects, first-hand experience, and illustrative media, rather than to merely communicate factual information. Based on one of the shorter definitions, interpretation involves »translating " a technical language into a language that nonscientists can readily understand (Ham 1992; Ogorelec 2004; Veverka et al. 2014). The purpose of modern and comprehensive landscape interpretation that exceeds the interpretation of natural and cultural heritage is to bring a specific topic closer to people in a comprehensible way in order to help them understand the landscape. This encourages them to explore further and think critically. The ultimate goal of landscape interpretation is for visitors to get to know the landscape and subsequently protect it against inappropriate changes. There is a proven link between interpretation and increased knowledge of the landscape and changed attitudes towards it (Wearing et al. 2008).

The mission for protected areas is not only to protect them, but also to make it possible for visitors to experience the nature, cultural heritage, and intangible values of a specific place. Arranging and presenting protected areas to visitors are among the important goals, operational aims, and hence relevant tasks of protected area managers. However, the presence of visitors in these usually sensitive ecosystems causes frequent disturbances that are not in line with the desired goal of protecting unique and diverse natural or cultural landscapes; therefore, visits to such areas must be carefully planned, guided, and supervised (Baldauf et al. 2011).

Designing an interpretation plan is one of the first steps in arranging protected areas for visitors, in which one needs to ensure that the best possible link is established between the landscape and the visitor. Planning the interpretation entails developing effective tools that are based on the mission and goals of the manager, the interests and needs of the visitors, and unique and important features of the landscape one wishes to present and thus encourage visitors to think. Effective tools are developed by answering the following three basic questions: What? Who? Why? (Gross, Zimmerman and Buchholz 2006). This article provides answers to »What? « and thus helps explain how the understanding of landscape and its components should be developed. The key question is which parts of the landscape and which events that happened in a specific area are worth explaining (Gross, Zimmerman and Buchholz 2006).

Literature on interpretation contains no methodology that could help interpreters with the initial stages of planning the interpretation of a selected landscape. The aim of this article is to present an approach to developing the bases for landscape interpretation using the case of the Ljubljana Marsh. This area was selected because it is one of the most radically transformed Slovenian landscapes. During the nineteenth century in particular, enormous amounts of peat were removed from the marsh, lowering its surface by several meters. Over the past 250 years, several thousand kilometers of drainage canals have been cut into it (Vidmar 2013), thereby drying out the majority of the land there. Its cultural landscape differs greatly from the original one, but it is still (or even precisely because of this) very interesting for interpretation. The study of the marsh proceeded from its natural geographical characteristics and the key human changes introduced over a thousand years of its development. The design of the landscape interpretation plan relied on the knowledge of its natural and cultural heritage, which provides deeper insight into the interconnection of people and nature. 


\section{The Ljubljana Marsh}

The Ljubljana Marsh is a large wet plain measuring just over $150 \mathrm{~km}^{2}$ in the southern part of the Ljubljana Basin interspersed with 15 to $100 \mathrm{~m}$ tall isolated, largely wooded hills (Pavšič 2008). The marsh basin is filled by fluvial deposits that cover its bedrock. At the end of the Pleistocene over ten thousand years ago, the Ljubljana Marsh is believed to have been covered by a large lake (Verbič and Horvat 2009), even though no general agreement has been reached about this among researchers. Thus, for example, Šifrer (1984) believes that there was no major lake formation in the marsh, but this does not mean there were no intermittent lakes there. In any case, floods are an important characteristic of the Ljubljana Marsh. Frequent or regular floods especially affect its central part, where approximately $15 \%$ of the terrain is under water.

The Ljubljana Marsh has been strongly influenced by the several thousand years of human presence, which is proved by numerous archeological finds, especially those from the Ljubljanica River. The first traces of settlement reach back to the early Mesolithic, when the marsh was populated by Mesolithic hunters (Gaspari 2009). The next important settlement era extends to the late Neolithic, when the inhabitants lived in pile dwellings. Major human interventions that significantly changed the marsh landscape began in the second half of the eighteenth century, when the marsh began to be systematically drained (Melik 1927; Melik 1946). The once extensive lowland raised bog, the southernmost and lowest in Central Europe, has now only been preserved in the form of small peat beds. Hence the typical bog characteristics are only preserved in the choronym Barje (literally, 'peatland, bog') or Ljubljansko barje (literally, 'Ljubljana peatland, bog').

After 150 years of human intervention in the marsh landscape, at the beginning of the twentieth century the first realizations appeared about the need to protect it (Spomenica ... 1920). Efforts to protect the Ljubljana Marsh intensified during the 1980s, until the marsh was protected as a landscape park in 2008 with the goal »to protect the natural values, preserve the biodiversity, and maintain and enhance the landscape diversity« (Uredba o Krajinskem ... 2008).

Despite being protected, the Ljubljana Marsh continues to face many pressures and threats that may endanger its future sustainable development. Recently, leisure activities have become increasingly important in the marsh in addition to agriculture and will have a strong impact on the future of this landscape. Because one of the main goals of protecting the Ljubljana Marsh is also »to enable research, education, relaxation, and spiritual enrichment of people « (Uredba o Krajinskem ... 2008), the interest of visitors is expected to increase, as are the need and care for preserving this exceptionally valuable area.

\section{The basis for interpreting the Ljubljana Marsh landscape}

An interpretation infrastructure plan was already made for the Ljubljana Marsh Nature Park at the time when it was established (Thaler et al. 2007). Potentially suitable locations were defined based on various criteria, with an emphasis on the physical setup. This article focuses on preserving and understanding the cultural landscape and especially its heritage using various interpretation tools, such as e-lessons and field assignments, which are not necessarily visible out in the field.

The prepared material is intended to help the manager select the areas for interpretation and develop the interpretation bases. One of the basic guidelines for managing protected areas was taken into account: the visitors and local communities must discover and understand the value and importance of heritage, which promotes attachment to the local environment and enhances the care for it.

Records, such as the registers of natural and cultural heritage (Pravilnik o določitvi ... 2004; Register nepremične kulturne ... 2015; Register žive kulturne ... 2015), Digital Encyclopedia of natural and cultural heritage - DEDI (2015), protected area management plans, and municipal and other material, were reviewed through desk research, and based on an expert assessment the potential areas for landscape interpretation were defined. The next step involved expanding the materials prepared in the office by including findings obtained in the field (by inspecting the area and conducting interviews with the key stakeholders).

The areas were not selected based on quantitative criteria, which would have made it possible to rank topics and areas by relevance. For example, such criteria are used with established geomorphological evaluation methodologies (e.g., Erhartič 2012; Ciglič and Perko 2013; Erhartič, Zorn and Komac 2013). Primary 


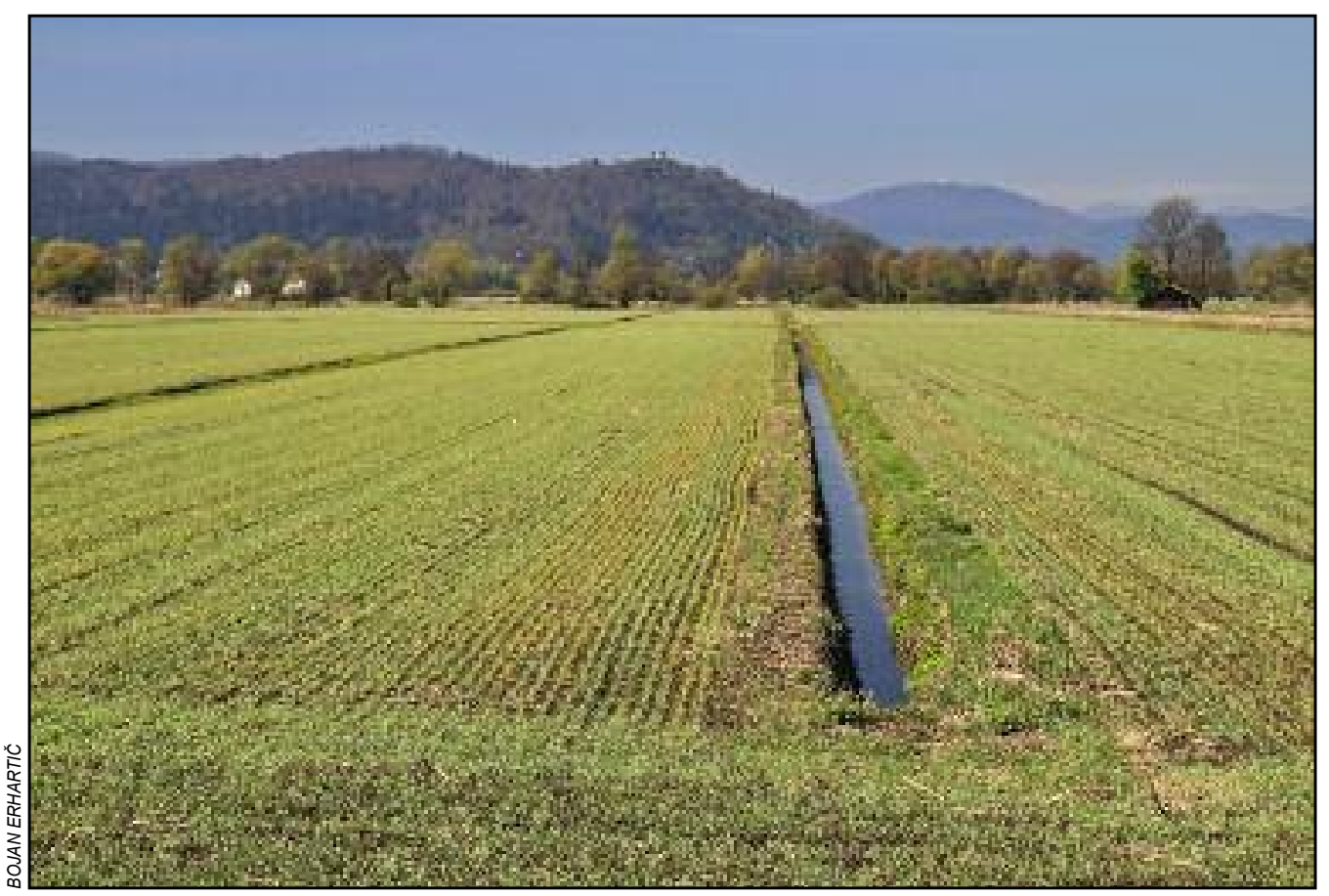

Figure 1: The Ljubljana Marsh is crisscrossed by numerous drainage channels.

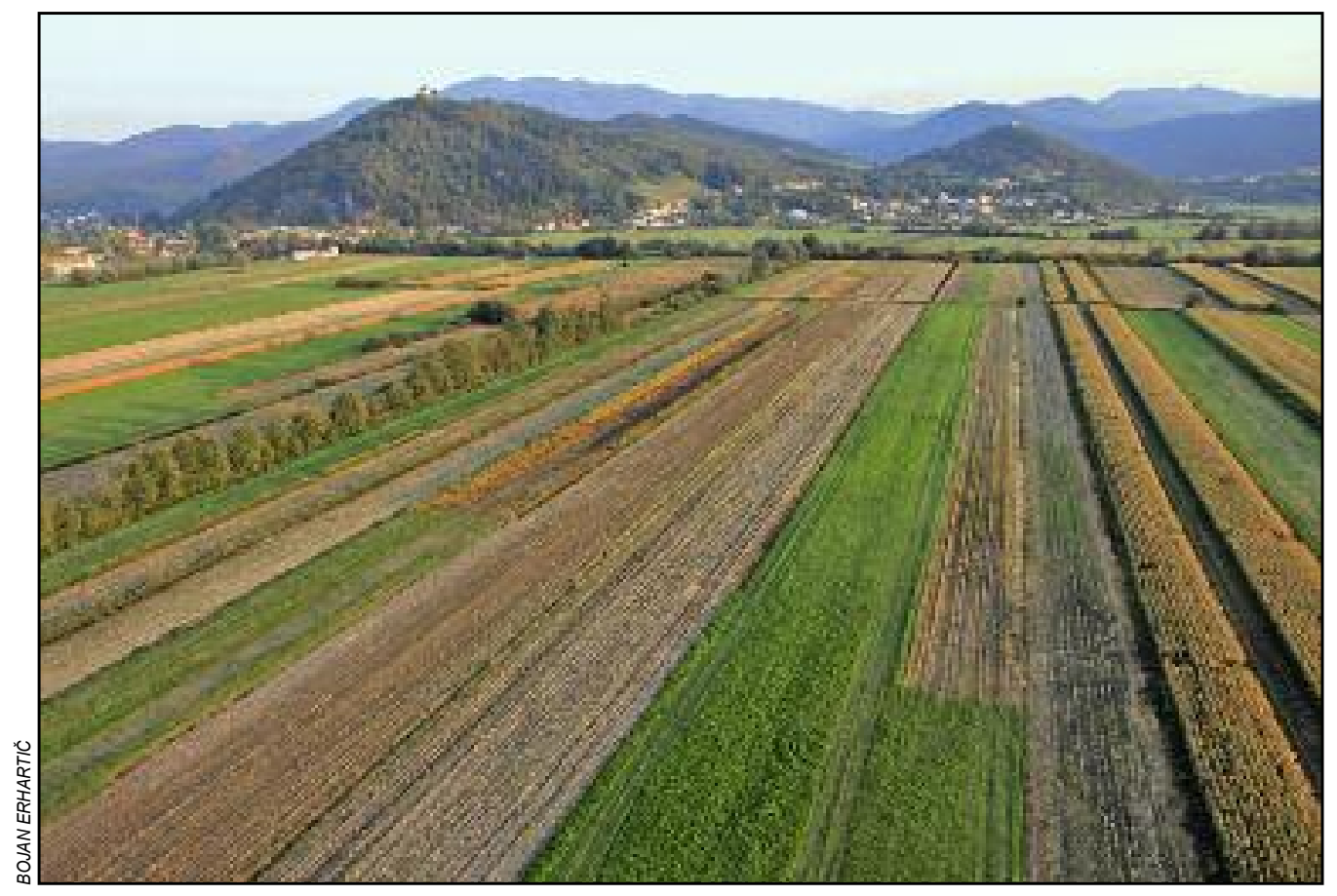

Figure 2: Aerial view of the mosaic-like landscape of the Ljubljana Marsh. 
Aleš Smrekar, Mateja Šmid Hribar, Jernej Tiran, Bojan Erhartič $\dagger$, A methodological basis for landscape interpretation ...

interest was placed on the lists of topics and suitable areas, which covered the diversity of the cultural landscape to the greatest possible extent. Based on this, the manager of the area or any other interested party will be able to prepare the interpretation. The following principles were taken into account in selecting the areas:

- Visitors should be directed to less vulnerable areas and away from more vulnerable ones,

- Visitors should be directed to areas with existing or planned infrastructure;

- Density of natural and cultural heritage units from official records;

- Additional values with interesting topics pointed out by the locals;

- Experiential diversity of the area and its educational potential.

Based on the case study of the Ljubljana Marsh Landscape Park, fifteen areas most suitable for interpretation were defined (Table 1).

Table 1: Proposed interpretation areas in the Ljubljana Marsh.

\begin{tabular}{|c|c|c|}
\hline Number & Name & Brief description \\
\hline 1 & Ljubljanica springs & $\begin{array}{l}\text { This area is characterized by the high-volume springs of the Ljubljanica River where the karst } \\
\text { and marsh landscapes meet. }\end{array}$ \\
\hline 2 & $\begin{array}{l}\text { Ethnological heritage of Bevke } \\
\text { and its surroundings }\end{array}$ & $\begin{array}{l}\text { This area is characterized by people's long-term coexistence with nature, demonstrated in rich } \\
\text { archeological and ethnological heritage. }\end{array}$ \\
\hline 3 & Old orientation points & $\begin{array}{l}\text { Churches on the hilly southern rims of the Ljubljana Marsh still serve as important orientation } \\
\text { and vantage points, and an important part of religious heritage. }\end{array}$ \\
\hline 4 & Iška River & $\begin{array}{l}\text { In its lower reaches, after exiting the lška Gorge, the lška River (a formerly meandering river that } \\
\text { has been trained) deposited a gravel fan with rich supplies of drinking water. }\end{array}$ \\
\hline 5 & Recent colonization of Črna Vas & $\begin{array}{l}\text { The Črna Vas area, crisscrossed by numerous drainage channels, was one of the last planned } \\
\text { colonization areas in Slovenia in } 1830 .\end{array}$ \\
\hline 6 & Iška Moor & $\begin{array}{l}\text { The lška Moor is one of the most extensive contiguous areas of wet meadows and herbaceous } \\
\text { plants in the Ljubljana Marsh. }\end{array}$ \\
\hline 7 & Ljubljanica River & $\begin{array}{l}\text { The Ljubljanica River is the central watercourse of the Ljubljana Marsh. In the past it was of } \\
\text { exceptional importance to people, which is confirmed by the numerous archeological artefacts } \\
\text { from various archeological periods found in it. }\end{array}$ \\
\hline 8 & Mali Plac & $\begin{array}{l}\text { The Mali Plac Nature Reserve is a former raised bog, which turned into a marsh because of } \\
\text { human intervention. }\end{array}$ \\
\hline 9 & Pile-dwellers at lg & $\begin{array}{l}\text { This area is characterized by the remnants of the pile-dwelling culture, a UNESCO World Heritage } \\
\text { site since } 2011 .\end{array}$ \\
\hline 10 & Substitute habitat near Mestni Log & $\begin{array}{l}\text { Because of the planned expansion of the nearby landfill, a substitute habitat is planned to be set } \\
\text { up in this area. }\end{array}$ \\
\hline 11 & $\begin{array}{l}\text { Quarries in Podpeč } \\
\text { and Notranje Gorice }\end{array}$ & $\begin{array}{l}\text { This area is known for the abandoned limestone quarry in Podpeč and the abandoned dolomite } \\
\text { quarry in Notranje Gorice. }\end{array}$ \\
\hline 12 & Habitats around Pijava Gorica & $\begin{array}{l}\text { This area is characterized by extremely diverse land use. It is largely covered by tilled fields } \\
\text { and meadows, and wet meadows can be found on its eastern edge. }\end{array}$ \\
\hline 13 & Nearby Karst area & $\begin{array}{l}\text { Karst features are typical of the southern rims of the Ljubljana Marsh. An interesting example } \\
\text { of this is Podpeč Lake, a karst lake with springs in and around it fed by the nearby karst area. }\end{array}$ \\
\hline 14 & Draga Valley and nearby area & $\begin{array}{l}\text { The Draga Valley has seven ponds created in the eighteenth century due to harvesting clay. } \\
\text { A fish hatchery was later set up in them. }\end{array}$ \\
\hline 15 & Technical heritage & $\begin{array}{l}\text { This area boasts rich technical heritage, among which the Southern Railroad with its accompanying } \\
\text { structures, and small hydroelectric plants are the most important. }\end{array}$ \\
\hline
\end{tabular}

Figure 3: Proposed interpretation areas in the Ljubljana Marsh. 
Acta geographica Slovenica, 56-2, 2016

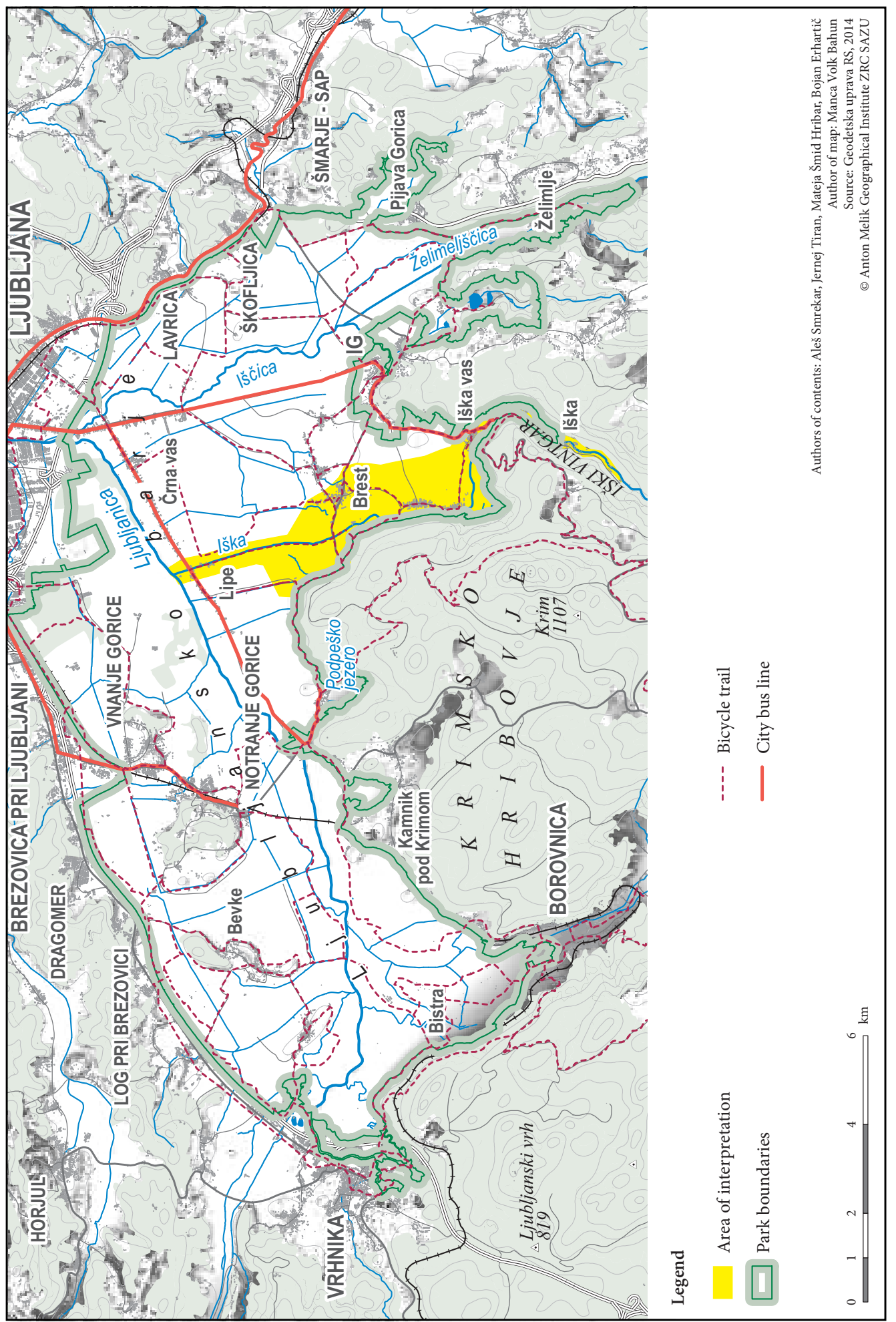




\subsection{Interpretation form}

A structured landscape interpretation basis was developed for every area using the form presented here. The form was designed and completed by taking into account the perspective of managers, who will be able to use the selected topics as a starting point for developing the landscape interpretation in a selected area. The form is transferrable to other environments, is easy to complete, and can be used by the specialist services of managers of various types of protected areas and by local communities. It consists of the following eight thematic categories:

- Location;

- Area outline;

- Natural and cultural heritage;

- Cultural value;

- Infrastructure;

- Landscape interpretation;

- Protection and potential vulnerability;

- Map.

The categories of the interpretation area location and outline provide a thorough presentation of the selected area: its location in the immediate and wider surroundings, a brief description of its relief features, bodies of water, predominant flora, land use, and key social geographical properties, such as the predominant type of settlement, population by settlement, and the socioeconomic structure of individual settlements.

\begin{tabular}{ll}
\hline I. LOCATION & Description \\
\hline Address & Potential protected area, region \\
\hline Wider area in question & Established name of the part of the region \\
\hline Immediate area in question & The municipality(ies) that the interpretation area belongs to. \\
\hline Municipality(ies) & The settlement(s) whose parts extend to the area of interpretation. \\
\hline Settlement(s) & The area of interpretation marked on the map of the wider region. \\
\hline Map & \\
\hline II. AREA OUTLINE & $\begin{array}{l}\text { Geographic location, relief properties, bodies of water, flora, predominant land use, settlement: } \\
\text { population, type of settlement (urban, suburban, rural, compact, scattered), economic activities }\end{array}$ \\
\hline Brief outline & Legislation that protects parts of the area or individual heritage units \\
\hline Protected areas &
\end{tabular}

The natural and cultural heritage category provides an inventory of the heritage sites in individual areas and is key for developing the themes, goals, and topics of the landscape interpretation. A desk inventory of the heritage sites is carried out for each area selected, in which both the units protected through legal acts and those that are only included in the official records are taken into account.

\begin{tabular}{|c|c|c|c|c|}
\hline \multicolumn{5}{|c|}{ III. NATURAL AND CULTURAL HERITAGE } \\
\hline \multicolumn{5}{|c|}{ List of natural heritage sites used for interpretation } \\
\hline Number & $\begin{array}{l}\text { Type (e.g., hydrological, geomorphological, zoological, } \\
\text { ecosystem etc.) }\end{array}$ & Name & Location ( $x$, y coordinates) & Description \\
\hline$\ldots$ & $\ldots$ & $\ldots$ & $\ldots$ & $\ldots$ \\
\hline$\ldots$ & $\ldots$ & $\ldots$ & $\ldots$ & $\ldots$ \\
\hline \multicolumn{5}{|c|}{ List of cultural heritage sites used for interpretation } \\
\hline Number & $\begin{array}{l}\text { Type (e.g., cultural landscape, buildings, archeological } \\
\text { sites, settlements and their parts etc.) }\end{array}$ & Name & Location ( $x, y$ coordinates) & Description \\
\hline$\ldots$ & $\ldots$ & $\ldots$ & $\ldots$ & $\ldots$ \\
\hline$\ldots$ & $\ldots$ & $\ldots$ & $\ldots$ & $\ldots$ \\
\hline \multicolumn{2}{|c|}{ Predominant types of heritage: } & $\begin{array}{l}\text { The pre } \\
\text { sites is }\end{array}$ & $\begin{array}{l}\text {-type of heritage in the lists of } \\
\text { ed (e.g. hydrological and arch }\end{array}$ & $\begin{array}{l}\text { and natural heritage } \\
\text { cal heritage). }\end{array}$ \\
\hline
\end{tabular}


The cultural value category lists various values that have not yet been recognized by the heritage protection profession and evaluates the interpretation areas in terms of cultural service provision. It takes into account the relaxation, aesthetic, inspirational, identification, spiritual, and educational values that the area offers to locals and visitors (e.g., Šmid Hribar 2014). The greater the number of types of cultural services provided by the area, the more important its cultural value.

IV. CULTURAL VALUE

Relaxation values Aesthetic values Inspirational values Identification values Spiritual/religious values Educational values

\begin{tabular}{llll}
\hline$\ldots$ & $\ldots$ & $\ldots$ & $\ldots$
\end{tabular}

The infrastructure category first focuses on the transport accessibility of the area by analyzing the traffic connections, with a special emphasis on sustainable modes of transport. Bus and railroad timetables are studied in detail, especially from the nearby local and regional centers and transportation hubs. This makes it possible to determine whether the existing conditions are suitable or what should be done in the future to improve accessibility (e.g., changing bus routes, building a bridge across a stream, build more hiking trails and cycle paths, and so on).

An inventory is made of the structures intended for supply, service, and leisure activities, such as restrooms, grocery stores, restaurants, ATMs, museums, places for equipment rental, accommodation, and so on. These activities are important for satisfying the general needs of visitors and, in terms of the hierarchy of needs, they are a precondition for attracting their attention (Ogorelec 2004). Interpretational arrangements, such as nature trail entry and exit points, are placed in areas with existing infrastructure.

\begin{tabular}{ll}
\hline V. INFRASTRUCTURE & \\
\hline Accessibility & $\begin{array}{l}\text { Bus, train, car, bicycle, cable car, on foot; (describe and provide suitable information, such as distance from } \\
\text { a given place, timetables, parking, etc.) }\end{array}$ \\
\hline Supply and service activities & $\begin{array}{l}\text { Portable toilets, grocery store, snack bar, restaurant, accommodation, vacation farm, information point, post } \\
\text { office, bank, ATM, gas station, cell phone coverage, Wi-Fi access (list available activities) }\end{array}$ \\
\hline $\begin{array}{l}\text { Leisure activities } \\
\text { Existing interpretation tools; hiking trails, cycle paths, riding trails, waterways, and similar; playground, sports } \\
\text { fields, and picnic areas; equipment rentals; museum. }\end{array}$ \\
\hline
\end{tabular}

The form's main focus is on landscape interpretation; specifically, its theme, goal, and topics. The theme is selected based on the predominant type of heritage in a specific area and is used as the central interpretation theme, such as the pile-dwelling culture in the Ljubljana Marsh. In this, recommendations for the theme to include a central idea, reflect the purpose of the interpretation, and be presented in an attractive and simple way are taken into account (Tilden 1957; Lewis 1981; Veverka 2011). After this, the goals of the interpretation are defined for the specific area. In line with the latest studies on working memory capacity (Cowan 2005), a maximum of three goals are defined, making sure they relate to the theme and follow one of the main purposes of landscape interpretation: to stimulate visitors to think (Tilden 1957). In the case of the pile-dwelling culture, these goals include the following: to get to know the settlements and lifestyle of pile-dwellers and how they adapted to their living conditions, and how lower groundwater levels endanger the in situ conservation of pile-dwelling sites. Then suitable material or topics are developed in order to reach the goals set. In the case of the pile-dwelling culture, the possible topics include the following: the presumed lake, swamp, peatland, piles, pile-dwelling settlement, material remnants, threat to the conservation of sites, and a typical pile-dweller's day.

In line with the selected theme, goals, and topics, the most suitable interpretation tools are suggested, such as e-lessons, information boards, mobile apps, private tours, reconstructions, field assignments, printed materials, outdoor classrooms, and nature trails. Various types of interpretation tools targeted at different groups of (both real and online) visitors make it possible to attract a wide variety of potential visitors of various ages, interests, and background knowledge. 
Aleš Smrekar, Mateja Šmid Hribar, Jernej Tiran, Bojan Erhartič $\dagger$, A methodological basis for landscape interpretation ...

\begin{tabular}{|c|c|}
\hline \multicolumn{2}{|c|}{ VI. LANDSCAPE INTERPRETATION } \\
\hline Interpretation theme & Central theme or motif of interpretation \\
\hline Interpretation goals & A maximum three goals are highlighted \\
\hline Interpretation topics & Selection of topics \\
\hline Interpretation tools & $\begin{array}{l}\text { Selection of tools: } \\
\text { - Low-cost (e.g., brochures, online descriptions, field assignments, private tours) } \\
\text { - Medium price range (e.g., e-lessons and mobile apps) } \\
\text { - Expensive (e.g., visitors'center, reconstructions, and outdoor classrooms) }\end{array}$ \\
\hline
\end{tabular}

If, based on the criteria described above, a selected area is identified as worthy of interpretation, the protection and potential vulnerability category is used to check the environmental carrying capacity and assess the area's potential vulnerability in terms of natural and cultural heritage conservation. The fundamental question is how many people can visit the selected area within a specific time range and in what way without degrading its environment. For example, visits are controlled by making visitors walk to the edge of the nature reserve and letting them see the reserve only in small, preferably guided, groups. Before making any changes or interventions, the manager must arrange a zonation of the interpretation area based on the legal bases, assessment of the environmental carrying capacity, the topics of interpretation, and proposed tools. In this, the manager defines where various visitor groups can spend time, what areas they can reach with various means of transport, and so on. Based on this assessment, it can be decided what additional infrastructure should be installed in the area, if at all. Only the legal bases for protecting the heritage in the selected area are entered in the form.

VII. PROTECTION AND POTENTIAL VULNERABILITY

Protected areas The type of protection in place (e.g., Strict Nature Reserve, Nature Reserve, Natural Monument, Natura 2000 site, Monument)

VIII. MAP

Thematic map

The location of the interpretation area is marked on a map, including the natural and cultural heritage units and infrastructure

\section{Conclusion}

Landscape interpretation is one of the most suitable, effective, and also demanding and complex processes of informing and raising the awareness of visitors and local residents in protected and other areas of interest. From its conceptual to implementing stage, this process demands a comprehensive and interdisciplinary approach. The relevant literature does not include any established guidelines on appropriate methodology for identifying the elements that are worth interpreting within a specific landscape.

A special methodology was designed that managers and interpreters can use to identify the areas for interpretation and their key potentials, and develop an interpretation basis by including various interpretation tools. The most useful part of this methodology is the interpretation form, which can be transferred to other landscapes and is simple to use. Using this form, managers will identify the key natural and cultural heritage sites, cultural values, infrastructure, and legal bases for protecting heritage in a specific area. The form serves primarily as a tool and the conceptual interpretation differs by individual case.

Fifteen areas were identified and evaluated as part of the case study of the Ljubljana Marsh Nature Park. The identification was based on the expert assessment, which subsequently allowed for a broader understanding of the landscape complexity. Quantitative evaluation would have only limited this process, and individual seemingly marginal (but exceptionally important) landscape components would have been lost.

In a cultural landscape it is difficult to draw a clear dividing line between nature and society. Similarly, despite Slovenia's administrative division, natural and cultural heritage are interconnected, which requires a comprehensive presentation in terms of landscape interpretation. The process of identifying topics of 
interest can be enriched by including an area's cultural values. Special attention must be paid to the most vulnerable areas in terms of natural and cultural heritage conservation when the manager wishes to present them to a selected audience. The most appropriate methods of interpreting heritage in the vulnerable areas include private in situ guided tours, interpretation centers, and the internet.

The selection of interpretation tools (e.g., field assignment database, e-lessons with teaching instructions, information boards, private guided tours, printed materials, outdoor classrooms, and nature trails) depends on the topics selected and target groups. The selected tools are targeted at various groups of people to convince them to come visit a specific landscape and try to understand the landscape they are visiting or even living in. This agrees with Cvahte's claim that quality interpretation not only influences people's knowledge, but also changes their behavior (Cvahte 2013).

Using the form presented, the manager will more easily achieve the ultimate goal of interpretation: for people to get to know the landscape and protect it against inappropriate changes by spreading knowledge about it and positive attitudes towards it.

An expert-based landscape interpretation does not result in commercialization of the area; on the contrary, it helps direct visitors and raise their awareness.

\section{References}

Baldauf, M., Ogorelec, B., Bogner, D., Brezavšček, L., Neuhold, U., Papež, A., Schitter, E., Šolar, M. 2011: Infrastruktura za doživljanje in spoznavanje narave. Smernice za inovativno načrtovanje. Bled.

Colquhoun, F. 2005: Interpretation handbook and standard: distilling the essence. Wellington.

Cowan, N. 2005: Working memory capacity: essays in cognitive psychology. New York.

Cvahte, A. 2013. Interpretacija naravne in kulturne dediščine v Triglavskem narodnem parku in Narodnem parku Fiordland (Nova Zelandija) v luči geografije. Diplomsko delo, Filozofska fakulteta Univerze v Ljubljani. Ljubljana.

DEDI. Digitalna enciklopedija naravne in kulturne dediščine na Slovenskem. Internet: www.dedi.si (27.1.2015). Erhartič, B. 2012. Geomorfološka dediščina v Dolini Triglavskih jezer. Geografija Slovenije 23. Ljubljana. Gaspari, A. 2009: Rimska regulacija Ljubljanice in osuševanje Barja. Ljubljanica: kulturna dediščina reke. Ljubljana.

Gross, M., Zimmerman, R., Buchholz, J. 2006: Signs, trails, and wayside exhibits: connecting people and places. Stevens Point.

Ham, S. H. 1992: Environmental interpretation: a practical guide for people with big ideas and small budgets. Golden.

Internet 1: http://www.nps.gov/home/historyculture/upload/MW,pdf,MillsBio,b.pdf (16.12. 2013).

Internet 2: http://www.enosmills.com/historypg2.html (16.12.2013).

Kye, J. C. 2005: Developing an interpretive planning model for a national park system: a stakeholder-based needs assessment study for Korea. Doctoral thesis, Ohio State University, School of environment and natural resources. Columbus.

Lewis, W. 1981: Interpreting for park visitors. Philadelphia.

Mackintosh, B.: Interpretation in the national park service: a historical perspective. Internet: http://www.cr.nps.gov/ history/online_books/mackintosh2/origins_before_nps.htm (16.12.2013).

Melik, A. 1927: Kolonizacija Ljubljanskega barja. Ljubljana.

Melik, A. 1946: Ljubljansko mostiščarsko jezero in dediščina po njem. Ljubljana.

Ogorelec, B. 2004: Interpretacija narave - od doživljanja do doživetja. Tematske poti na Krasu. Internet: http://www.interpretacija.si/arhiv/tematske_poti_kras.pdf (12.2.2014).

Pavšič, J. 2008: Neživi svet Ljubljanskega barja: geologija barja in njegovega obrobja. Ljubljansko barje, neživi svet, rastlinstvo, živalstvo, zgodovina in naravovarstvo. Ljubljana.

Pravilnik o določitvi in varstvu naravnih vrednot. Uradni list Republike Slovenije 111/2004, 70/2006, 58/2009, 93/2010. Ljubljana.

Register nepremične kulturne dediščine. Ministrstvo za kulturo. Ljubljana. Internet: http://www.mk.gov.si/ si/storitve/razvidi_evidence_in_registri/register_nepremicne_kulturne_dediscine/ (27.1.2015).

Register žive kulturne dediščine. Ministrstvo za kulturo. Ljubljana. Internet: http://www.mk.gov.si/si/ storitve/razvidi_evidence_in_registri/register_zive_kulturne_dediscine/seznam_registriranih_enot_zive_ kulturne_dediscine/ (27.1.2015). 
Spomenica Odseka za varstvo prirode in prirodnih spomenikov. Glasnik Muzejskega društva za Slovenijo, 1920. Internet: http://www.arhiv.mop.gov.si/fileadmin/mop.gov.si/pageuploads/publikacije/drugo/spomenica.pdf (5.3.2014).

Šifrer, M. 1984: Nova dognanja o geomorfološkem razvoju Ljubljanskega barja. Geografski zbornik 23.

Šmid Hribar, M. 2014: Trajnostno varovanje in usmerjanje razvoja kulturne pokrajine na izbranem območju Krajinskega parka Ljubljansko barje. Doktorska disertacija, Fakulteta za humanistične študije Univerze na Primorskem. Koper.

Thaler, J., Dalla Valle, K., Dalla Valle, S., Kolenbrand, N. 2007: Celovit načrt interpretacijske infrastrukture na območju Krajinskega parka Ljubljansko barje. Zaključno poročilo projekta. Ljubljana.

Tilden, F. 1957: Interpreting our heritage. Chapel Hill.

Uredba o Krajinskem parku Ljubljansko barje. Uradni list Republike Slovenije 112/2008. Ljubljana.

Verbič, T., Horvat, A. 2009: Geologija Ljubljanskega barja. Ljubljanica: Kulturna dediščina reke. Ljubljana.

Veverka, J. 2011: Interpretive master planning. Edinburgh.

Veverka, J. \& Associates: What is Interpretation. Internet: http://www.heritageinterp.com/whatis.htm (22.5.2014)

Vidmar, A. 2013: Andrej Vidmar, Fakulteta za gradbeništvo in geodezijo. Ocena dolžine kanalov na Ljubljanskem barju (23.10.2013).

Wearing, S., Edinborough, P., Hodgson, L., Frew, E. 2008: Enhancing visitor experience through interpretation. Brisbane. Internet: http://www.crctourism.com.au/wms/upload/resources/80035_Wearing EnhancingVis Exp_WEB.pdf (12.1.2014). 